\title{
Coastal and marine impact assessment for the development of an oil spill contingency plan: the case study of the east coast of Sicily
}

\author{
L. de Santoli, F. Cumo, D. Astiaso Garcia \& D. Bruschi \\ CITERA (Interdisciplinary Centre for Housing, Heritage and \\ Environment) Faculty of Architecture "Sapienza" University, \\ Rome, Italy
}

\begin{abstract}
This project is one of the results of the multi-year collaboration in coastal and marine sustainable management, planning and policy between the General Directorate for Nature and Sea Protection of the Italian Ministry for the Environment, Land and Sea and the CITERA Research Centre (Centro Interdisciplinare Territorio, Edilizia, Restauro, Ambiente) of the Sapienza University of Rome. The main objective of the project was to analyze the parameters involved in preparedness, prevention and response actions required by the Italian Ministry for the setting up of an Oil Spill Contingency Plan. Due to its critical anthropic impacts and its huge environmental heritage in terms of biodiversity richness and coastal geomorphological variety, the Eastern Sicily coastline, bounded by the geographic vertices of Cape Peloro and Cape Passero, has been chosen as the study area. Moreover this area is characterized by significant economic activities such as fishing and tourist industries. One of the major aims of the study was to rank coastal areas on the basis of their sensitivity to an unforeseen oil spill. Physical, geomorphological, biological and environmental attributes have been gathered using remote sensing techniques and field works, and they have been subsequently elaborated for the valuation of oil spill environmental sensitivity indices (ESI). In addition to ESI values, the elaborated maps contain other important information like landscaping and environmental constraints, human-use resources, archaeological and historical sites, and marine benthic biocenosis. In order to achieve the tasks and draw up the maps, the whole data set has been reported in a Geographical Information System (GIS) database. The obtained results include operational maps
\end{abstract}


representing useful tools for local stakeholders and practical guidelines for the elaboration of a regional oil spill contingency plan.

Keywords: oil spill contingency plan, marine impact assessment, risk assessment, GIS database.

\section{Introduction}

The progressive increase of sea traffic since the 1960s has caused growing concern for one of the fundamental aspects of pollution prevention: avoiding spills of hydrocarbons into the sea, which is particularly damaging to waters that are closed and subjected to heavy traffic such as the Mediterranean Sea [1].

Nowadays it is known that the majority of the hydrocarbons present in the sea comes from anthropogenic sources and represents a serious cause of marine pollution. As recently observed in the last environmental disasters in the Gulf of Mexico, oil spills can bring substantial damages to marine ecosystems, causing a loss of biodiversity with the consequent instability of fragile environmental balances. Moreover, as considered by the International Union for Conservation of Nature (IUCN), the Mediterranean basin is recognised as a biodiversity hotspot: its flora diversity is outstanding with 15,000 to 25,000 species, $60 \%$ of which are unique to the region and about one third of the Mediterranean fauna is endemic [2]. Furthermore, in recent years, a significant increase in the volume of crude oil and petroleum products transported in the Mediterranean Sea has been recorded: representing less than $1 \%$ of surface water in the world, about one third of the total traffic of oil was recorded in the Mediterranean Sea. Due to its central position, about half of all the crude oil that arrives each year in the Mediterranean ports, is directed to Italy [3].

This paper resulted from the multi-year collaboration between the General Directorate for Nature and Sea Protection of the Italian Ministry for the Environment, Land and Sea and the CITERA Research Centre (Interdisciplinary Centre for Housing, Heritage and Environment) of the Sapienza University of Rome. Starting from the case study of a specific area, Eastern Sicily, as well as offering a powerful instrument for reducing pollution in coastal waters, the aim is to provide protection for the Italian coastline, which is an important resource in terms of the natural, economic, social, historical and cultural phenomena. It is necessary to implement an integrated management and control of the whole area to preserve or recover its environmental integrity, optimising the cost/benefit ratio and continually improving the quality of human life and local communities in the area.

Ultimately, compared to the high probability of an oil spill in the Mediterranean Sea, this research wishes to provide useful tools and practical guidelines for planning the actions of prevention, preparedness and response required for the creation of a Contingency Plan in case of oil spills, through the classification of coastal areas on the basis of their sensitivity to an unforeseen oil spill and the creation of environmental sensitivity maps. To achieve these objectives, this research, after a short description of the legislative framework on 
sea pollution, provides some oil spill sensitivity maps of Eastern Sicily, bordered by the geographic vertices of Cape Peloro and Cape Passero.

\section{Regulatory framework}

The legislative framework for environmental issues and in particular for sea protection issues is constantly developing. Therefore, to avoid engaging into a misleading legal disquisition, but at the same time to get an idea on the subject, below is offered a simple overview of the normative levels that govern this matter.

At global level, there are several international conventions that deal with maritime safety and prevention of marine pollution. Among these, the most significant are:

- International Convention relating to Intervention on the High Seas in Cases of Oil Pollution Casualties (IHSOPC 1969), as amended by the related Protocol of 1973: it is the first International Convention that deals with marine oil pollution and it affirms the right of a coastal State to take such measures on the high seas as may be necessary to prevent, mitigate or eliminate danger to its coastline or related interests from pollution by oil or the threat thereof, following upon a maritime casualty;

- International Convention on Civil Liability for Oil Pollution Damage, as amended by the Protocols of 1976 and 1992 relating thereto (CLC 1969): it ensures that adequate compensation is available to persons who suffer oil pollution damage resulting from maritime casualties involving oil-carrying ships;

- International Convention for the Prevention of Pollution from Ships, as amended by the Protocols of 1978 and 1997 relating thereto (MARPOL 73/78): it aims at preventing and minimizing pollution from ships, both accidental pollution and that from routine operations. It currently includes six technical Annexes;

- International Convention on Oil Pollution Preparedness, Response and Cooperation, as amended by the Protocol of 2000 relating thereto (OPRC 1990): it provides for international co-operation in combating major incidents or threats of marine pollution. Parties are required to establish measures for dealing with pollution incidents, either nationally or in cooperation with other countries. Ships and operators of offshore units are required to have an oil pollution emergency plan, to be developed by IMO [4]; and

- Third United Nations Conference on the Law of the Sea (UNCLOS III, 1973-1982).

As regards the specific case study of the Mediterranean Sea, a convention that extends the international legislative framework related to marine pollution is the Convention for the Protection Of The Mediterranean Sea Against Pollution (Barcelona Convention).

Indeed, after the creation of the United Nations Environment Programme (UNEP) Regional Seas Programme in 1974, the Mediterranean became the first region to adopt an Action Plan (Mediterranean Action Plan - MAP) in 1975. This 
was quickly followed by the adoption of the Convention for the Protection of the Mediterranean Sea against Pollution (Barcelona Convention) in 1976, which entered into force in 1978, and a succession of seven landmark Protocols. In 1976, a Conference of Plenipotentiaries representing sixteen Mediterranean coastal States and the European Communities adopted the Convention for the Protection of the Mediterranean Sea Against Pollution (Barcelona Convention), which aims at protecting the marine environment and coastal zones through prevention and reduction of pollution, and as far as possible, elimination of pollution, whether land or sea-based. Finally, in 1995, the Action Plan for the Protection of the Marine Environment and the Sustainable Development of the Coastal Areas of the Mediterranean (MAP Phase II) was adopted, replacing the Mediterranean Action Plan of 1975.

\section{Study area}

The study area (Fig.1) forms part of Sicilian coastline which starts from Cape

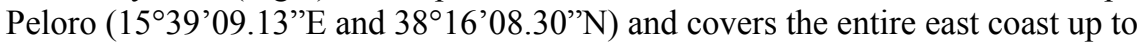

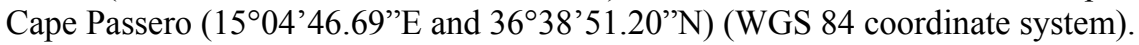

This specific area was chosen as case study due to its critical anthropic impacts and its huge environmental heritage in terms of biodiversity richness and coastal geomorphological variety. Moreover this area is characterized by significant economic activities like fishing and tourist industries.

From the geomorphological point of view, these coastlines include bays, estuaries, rocky headlands, sandy beaches, creeks and cliffs. In order to simplify the study area description, it was divided into 8 segments (stretches), resulting in about 416 kilometres of shoreline classification.

Moreover, this specific Italian coast area was chosen for its real risk of an oil spill given the strong oil activities and for its particularly critical anthropicenvironmental features. Indeed, in addition to the strong urban concentration and the great service industry presence along the coast, the stretch of sea in front of is characterized by one of the most intense maritime transit of the Mediterranean seas. Furthermore, the whole study area is characterized by a high seismic instability, factor that can potentially contribute to rage natural disasters.

Therefore, the Eastern Sicily coastline appears to be a highly sensitive zone, not only for its habitats and ecosystems uniqueness and diversity, but also and for its shipping traffic and its hydrographical and meteorological factors (in particular, with regard to the strong currents that affect the east coast of Sicily sea) that considerably increase the probability of maritime accidents and consequently the risk of marine and coastal pollution.

Due to its high environmental value, in this zone there are a significant number of protected areas that have important natural values. Among these there are 18 Sites of Community Importance (SCI areas), 8 Special Protection Areas (SPA areas) and one Ramsar area (wetlands of international importance). This area supports also many endemic plants and animals. On the marine side, besides the presence of two MPAs (Marine Protected Areas) (Cyclops Islands and Plemmirio), the relevance of this area should be stressed as important resting and nesting sites for many migratory birds species. 


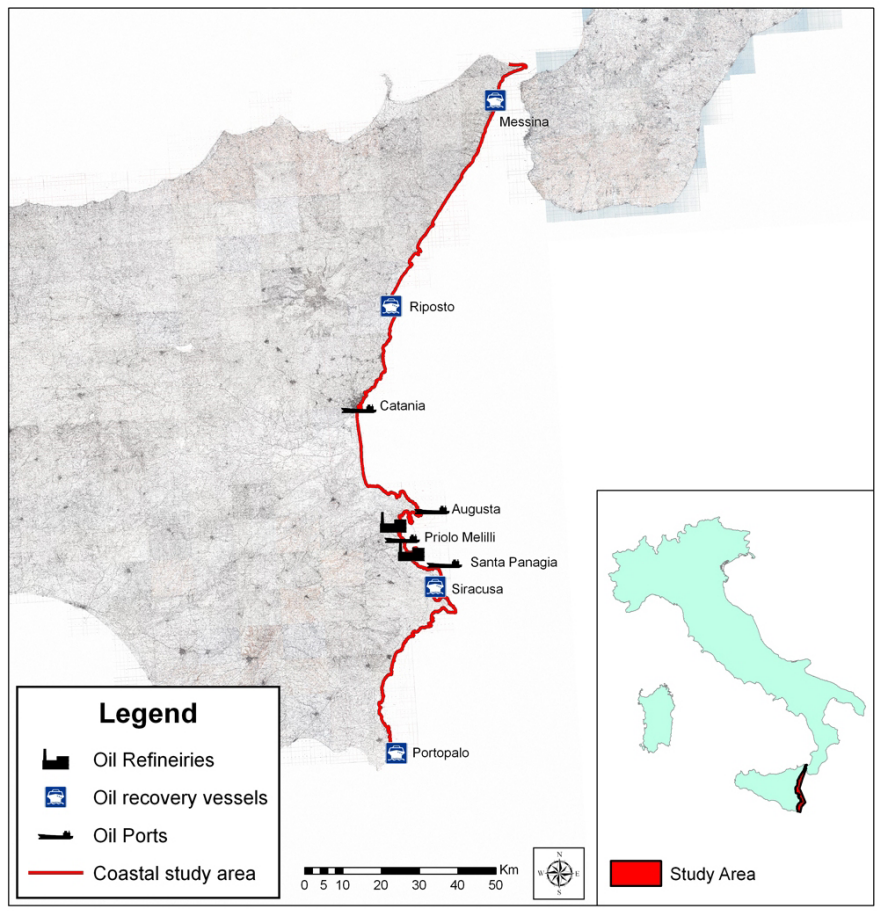

Figure 1: $\quad$ Oil ports, refineries and facilities along the study area.

With regard to the strong oil activities, this area is marked by heavy petroleum traffic. In fact, this zone is crossed by thousands of ships, especially ships carrying dangerous or polluting materials such as oil tankers, chemical tankers and gas carriers. Many of these are now obsolete or without the double hull or equivalent technologies. Besides the heavy commercial vessel traffic, along the coast there are 4 oil ports - Augusta, Priolo Melilli, Catania e Santa Panagia - in which more than 23 million tonnes of crude oil are landed each year (about $20 \%$ of total oil unloaded in Italy) and 2 oil refineries, Priolo and Augusta (figure 1); particularly the Priolo refinery is one of the biggest in the whole Mediterranean sea).

In addition, the port of Messina, located at the north of our study area, holds the record for carried passenger numbers between all the Italian ports: considering boarding and disembarkation, it records more than 10 millions of passengers every year [5].

Finally, to make a complete risk assessment of oil spills, it should be considered the huge amount of oil and hydrocarbon components carried through the sea in the petrol tank of ferries, pleasure crafts, fishing boats and merchant ships.

\section{Methods}

Between all the coastal hazards and pollutants, oil spills are certainly one of the most damaging because of they may bring long term impacts on coastal and 
marine habitats. According to the International Tanker Owners Pollution Federation (ITOPF), the oil spills impacts depend on a range of factors, from spill size and physicochemical characteristics of the oil, to weather conditions (e.g. waves intensity and frequency) [6].

Even if it is not possible to predict the impacts of an oil spill with any certainty, it's possible to evaluate the vulnerability of a specific area to a defined spill scenario based on the economics, environmental and cultural resources present in that marine zone.

This paper describes the design and development of the coastal prioritisation index taking into account the vulnerability of natural-cultural and socioeconomic resources. The creation of maps, elaborated considering all the criticality criteria, represents an important key activity in the production of contingency plans about the oil spill at sea. It is fundamental, that these maps can show which areas need prior action, thus providing to decision makers and stakeholders essential information for the protection of the entire coastline.

Therefore, to classify the impacts related to an oil spill, it was considered the appropriate methodology published by the International Maritime Organization (IMO) and by the International Petroleum Industry Environmental Conservation Association (IPIECA) [7], which, in its turn, is built on the work proposed by the Federal U.S. NOAA (National Oceanic and Atmospheric Administration) [8]. However, in order to consider carefully the whole archaeological or historical sites that typically marks the Italian and generally the Mediterranean coastlines, some changes have been made. In fact, in the Mediterranean context, the historical elements have such an inestimable value that should be considered in a balanced evaluation process with the ecological and socio-economical aspects.

Physical, geomorphological, biological and environmental attributes have been gathered using remote sensing techniques and field works that, subsequently, have been elaborated by the evaluation of oil spills environmental sensitivity indices (ESI). Remote sensing and Geographical Information System (GIS) software played a very significant role in the mapping of different classes of shoreline and for preparing different thematic layers. Moreover, in order to implement these gathered data, the Sicily's shoreline coastal habitats mapping was performed also with the support of WebGis informative systems like the Italian National Cartographic Portal (PCN) and the network of the Italian National Environmental Information System (Sinanet). In the end, to draw up the maps, the whole data set has been reported in a GIS database containing a comparative spatial analysis in order to classify on nationwide, the criticalities of Italian coast and seawaters.

\subsection{Shoreline classification}

As mentioned before, the Eastern Sicily shoreline classification and its consequential analysis in this study are based on the ESI methodology created by NOAA, which was modified and adapted in order to properly map these Mediterranean coastlines. According to this methodology, habitats would be 
more or less sensitive to oil spills according to their degree of exposure to hydrodynamic action and substrate characteristics [9]. The different types of habitat identified and their associated main characteristics are listed in Table 1.

Table 1: Values of coastal environmental sensitivity indices to oil spill impacts.

\begin{tabular}{|c|c|c|c|}
\hline $\begin{array}{c}\text { Vulnerability } \\
\text { Index }\end{array}$ & $\begin{array}{l}\text { GIS } \\
\text { Code }\end{array}$ & $\begin{array}{c}\text { Coast } \\
\text { Features }\end{array}$ & $\begin{array}{l}\text { Comments on } \\
\text { environmental } \\
\text { rehabilitation }\end{array}$ \\
\hline $\begin{array}{l}\text { 1.A Exposed high } \\
\text { rocky shores } \\
\text { 1.B Exposed artificial } \\
\text { coastal structures }\end{array}$ & CRAE & $\begin{array}{l}\text { Rocky shores with } \\
\text { steep slope exposed to } \\
\text { the action of waves, } \\
\text { which produce a } \\
\text { natural and fast oil } \\
\text { removal. The substrate } \\
\text { is waterproof }\end{array}$ & $\begin{array}{l}\text { It is not required or recommended } \\
\text { any type of intervention }\end{array}$ \\
\hline $\begin{array}{l}\text { 2. Exposed low } \\
\text { waterproof coasts }\end{array}$ & CBIE & $\begin{array}{l}\text { As for the index } 1 \text {, the } \\
\text { action of waves and } \\
\text { the natural forces of } \\
\text { sea remove most of the } \\
\text { oil in a few weeks. } \\
\text { The substrate is } \\
\text { waterproof ( rocky or } \\
\text { clay lithology) }\end{array}$ & $\begin{array}{l}\text { In most cases there is no need of } \\
\text { cleaning. The only problem could } \\
\text { be the possible presence of } \\
\text { sediment because of the } \\
\text { morphology of the coast }\end{array}$ \\
\hline $\begin{array}{l}\text { 3. Compact clay or } \\
\text { muddy sand beaches }\end{array}$ & $\mathrm{SSC}$ & $\begin{array}{l}\text { Grain size of sand } \\
<0.06 \mathrm{~mm} \text {. The } \\
\text { compactness of the } \\
\text { grains of the beach } \\
\text { prevents the deep } \\
\text { penetration of oil. The } \\
\text { use of specific } \\
\text { machinery is often } \\
\text { required for clean-up } \\
\text { interventions. The } \\
\text { substrate is semi- } \\
\text { waterproof }\end{array}$ & $\begin{array}{l}\text { Intervention measures } \\
\text { recommended: } \\
\text { 1. wait until all the oil has been } \\
\text { deposited on the beach; } \\
\text { 2. not repeatedly switch on the } \\
\text { areas where there is oil; } \\
\text { 3. remove only the amount of } \\
\text { contaminated sand. It is } \\
\text { recommended manually collect of } \\
\text { the sediments. }\end{array}$ \\
\hline 4. Sandy beaches & SS & $\begin{array}{l}\text { Grain size of sand: } \\
0.06-1.0 \mathrm{~mm} \text {. The } \\
\text { substrate is permeable } \\
\text { and the oil penetrating } \\
\text { average } 25 \mathrm{~cm} \text { in } \\
\text { depth }\end{array}$ & $\begin{array}{l}\text { The oil can penetrate deeply in } \\
\text { the sand. Difficult clean-up } \\
\text { operations. At the beginning, the } \\
\text { action of the waves makes the } \\
\text { burial of oil, while in the medium } \\
\text { long term it will remove most of } \\
\text { the oil (several months). It is } \\
\text { recommended to use specific } \\
\text { machines. }\end{array}$ \\
\hline $\begin{array}{l}\text { 5. Mixed sand and } \\
\text { gravel beaches }\end{array}$ & SM & $\begin{array}{l}\text { The substrate has a } \\
\text { medium-high } \\
\text { permeability. The oil } \\
\text { easily penetrates up to } \\
50 \mathrm{~cm} \text { deep, and its } \\
\text { burial can happen in a } \\
\text { few days. }\end{array}$ & $\begin{array}{l}\text { The oil in this type of beaches } \\
\text { may remain for a long time. } \\
\text { Moreover, its removal can be } \\
\text { very difficult. }\end{array}$ \\
\hline
\end{tabular}


Table 1. Continued.

\begin{tabular}{|c|c|c|c|}
\hline $\begin{array}{l}\text { 6.A Gravel and pebbles } \\
\text { beaches } \\
\text { 6.B Natural coasts with } \\
\text { blocks of stone melted } \\
\text { 6.C Artificial reef }\end{array}$ & $\mathrm{CNP}$ & $\begin{array}{l}\text { Grain size: } 1-256 \mathrm{~mm} \\
\text { and above. The } \\
\text { substrate is highly } \\
\text { permeable and it has a } \\
\text { high absorption } \\
\text { capacity. The oil can } \\
\text { penetrate up to } 1 \text { meter } \\
\text { deep }\end{array}$ & $\begin{array}{l}\text { The natural rate of removal is } \\
\text { very low, so oil removal from } \\
\text { these beaches is very laborious. } \\
\text { When a beach was highly oil } \\
\text { contaminated, it is practically } \\
\text { impossible to clean without } \\
\text { removing a large amount of } \\
\text { sediment. This could be very } \\
\text { harmful to the biocenosis present } \\
\text { in the area. In the case of artificial } \\
\text { reefs the only way to clean them } \\
\text { is to remove and replace them. }\end{array}$ \\
\hline $\begin{array}{l}\text { 7. Exposed tidal flats } \\
\text { coasts }\end{array}$ & CEM & $\begin{array}{c}\text { The substrate is } \\
\text { permeable. Generally, } \\
\text { the oil is not stagnant } \\
\text { and does not penetrate } \\
\text { into the soil }\end{array}$ & $\begin{array}{l}\text { Interventions are necessary only } \\
\text { to prevent contamination of } \\
\text { surrounding areas. In fact, the } \\
\text { tidal action involves a natural } \\
\text { cleaning action. The use of the } \\
\text { equipment should be used only if } \\
\text { the presence of oil is very intense }\end{array}$ \\
\hline $\begin{array}{l}\text { 8.A Sheltered rocky } \\
\text { shores } \\
\begin{array}{c}\text { 8.B Sheltered artificial } \\
\text { coastal structures }\end{array} \\
\text { 8.C Sheltered low } \\
\text { waterproof coasts }\end{array}$ & $\begin{array}{l}\text { CRR } \\
\text { ACR }\end{array}$ & $\begin{array}{c}\text { The substrate is hard } \\
\text { and mostly composed } \\
\text { by rock, artificial } \\
\text { material or clay }\end{array}$ & $\begin{array}{l}\text { These areas are sheltered from } \\
\text { waves and ocean currents. Oil } \\
\text { pollution can remain for years. } \\
\text { Both in the presence of } \\
\text { impermeable rock or more } \\
\text { permeable materials, due to the } \\
\text { strong presence of biological } \\
\text { activity and the low rate of } \\
\text { natural removal, it is often } \\
\text { necessary a cleaning action even } \\
\text { if it will be difficult and invasive. } \\
\text { For this reason are not } \\
\text { recommended cleaning } \\
\text { operations, unless oil is not } \\
\text { present in large quantities }\end{array}$ \\
\hline $\begin{array}{l}\text { 9. Sheltered tidal flats } \\
\text { coasts }\end{array}$ & CRM & $\begin{array}{c}\text { The substrate is semi- } \\
\text { waterproof }\end{array}$ & $\begin{array}{l}\text { These areas are characterized by } \\
\text { small waves, but with strong } \\
\text { organic production. Interventions } \\
\text { are not recommended except in } \\
\text { the case of major pollution. The } \\
\text { removal of oil is in fact } \\
\text { impossible without compromising } \\
\text { the conservation of the biological } \\
\text { communities. }\end{array}$ \\
\hline $\begin{array}{l}\text { 10. Marshes and } \\
\text { brackish coasts }\end{array}$ & $\mathrm{CP}$ & $\begin{array}{l}\text { The substrate typology } \\
\text { varies depending on } \\
\text { the particular } \\
\text { characteristics of each } \\
\text { considered area }\end{array}$ & $\begin{array}{l}\text { The protection of these areas } \\
\text { should generally have the highest } \\
\text { priority. In fact, in terms of } \\
\text { biological activity, these areas are } \\
\text { the richest and the most } \\
\text { productive marine environments. } \\
\text { Moreover, given the very low rate } \\
\text { of natural removal, oil may } \\
\text { remain in these areas for more } \\
\text { than } 10 \text { years. The environmental } \\
\text { restoration of these habitats } \\
\text { requires about } 20 \text { years. }\end{array}$ \\
\hline
\end{tabular}


The mapping process is achieved using coloured lines to represent the different shoreline types, and a standardized colour code is associated to each sensitivity value. The ESI classification is a convenient form to summarize information relating to the coast and does not take into account some possible uses of the considered coasts. For example, an exposed high rocky shore ranked with ESI 1 (low sensitivity) could accommodate an internal colony of seabirds with high sensitivity, at least during the breeding season. Or a sandy coast, with ESI 3 (relatively low sensitivity), could be an important site for tourism or for spawning by sea turtles in a given year (Caretta caretta in the Sicilian coast). Therefore in this study are presented ESI maps that implement the ESI classification with other biological and human-use information.

\section{Results}

In addition to ESI shoreline classification, the elaboration of an oil spill contingency plan is also related to the analysis of biological and human-use resources like: landscaping and environmental constraints, archaeological and historical sites, marine benthic biocenosis, etc.

Therefore, given the amount of information contained in these sensitivity maps, in order to make them more user friendly, it was decided to divide these information, thus obtaining two types of maps for each area analyzed (figures 2 and 3).

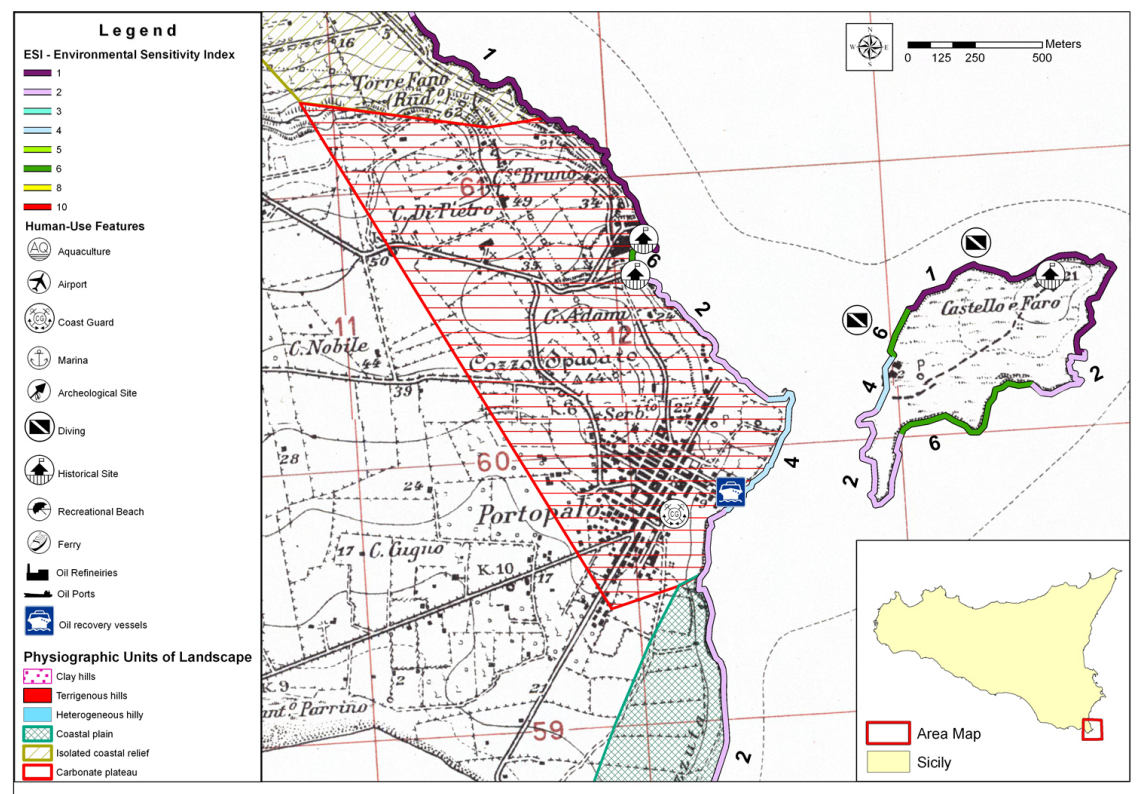

Figure 2: Environmental sensitive indices, human-use features and physiographic units of landscape in a coastal zone of the study area. 


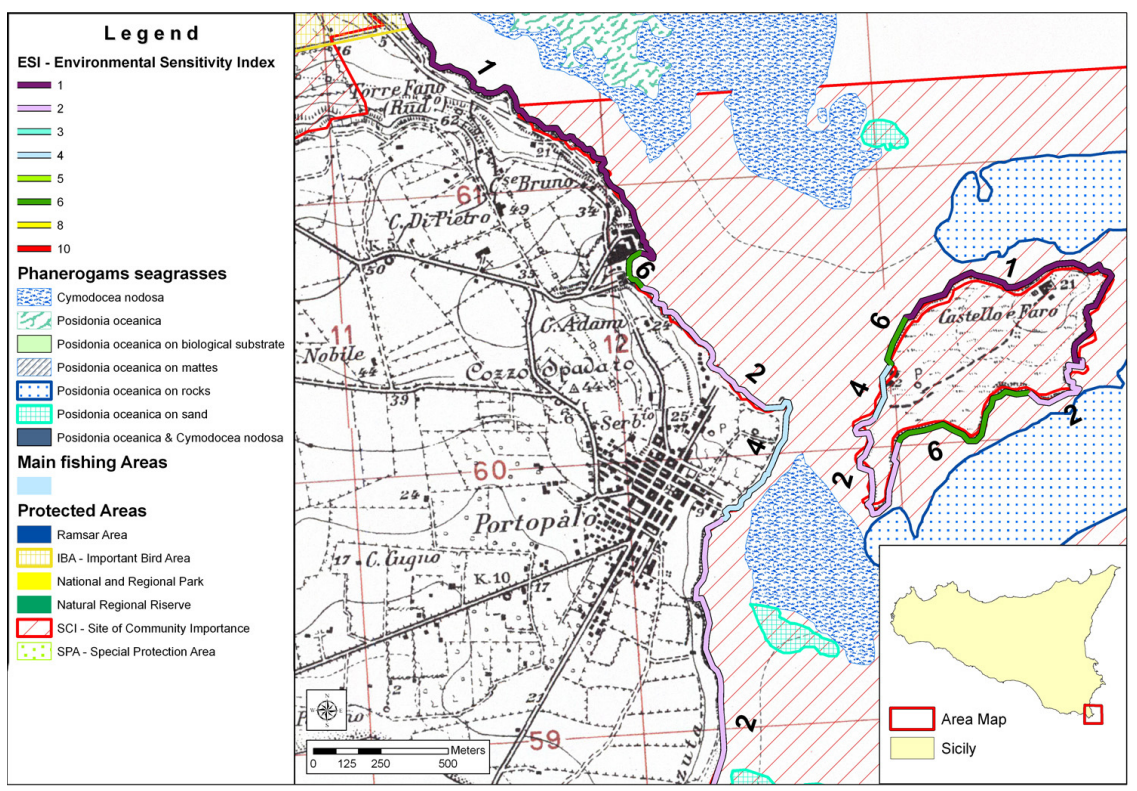

Figure 3: Environmental sensitive indices, marine phanerogams grasslands, main fishing and protected areas in a coastal zone of the study area.

Thus, these maps consider three main types of information:

1. the ESI classification, according to a scale which takes into account the different response capacities of each type of coast against a possible impact on oil-spill, considering the natural behaviour of oil and the ecological resilience of the area;

2. the presence of biological resources, defined as rare and protected animals, plants and entire habitats;

3. the presence of human activities, such as the existence of parks and marine reserves, archaeological sites, areas of aquaculture, etc.

The total length of the analyzed shoreline is about $416 \mathrm{~km}$, and specifically $308 \mathrm{~km}$ of natural coastal habitats and $108 \mathrm{~km}$ of artificial coastline. In the whole zone the most present ESI value recorded is 6, while there are no coastal areas characterized by 6 or 7 ESI value.

Therefore, in order to plan oil spill response actions the obtained results emphasize the importance of identify coastal areas with higher ESI values along a shoreline generally represented by low or medium sensitivity.

Otherwise, the presence of fragile ecosystems and habitats, not to mention the significant human-use coastal resources and historical/archaeological sites makes Eastern Sicily shorelines an area of high priority in the management of a national or regional contingency plan. 


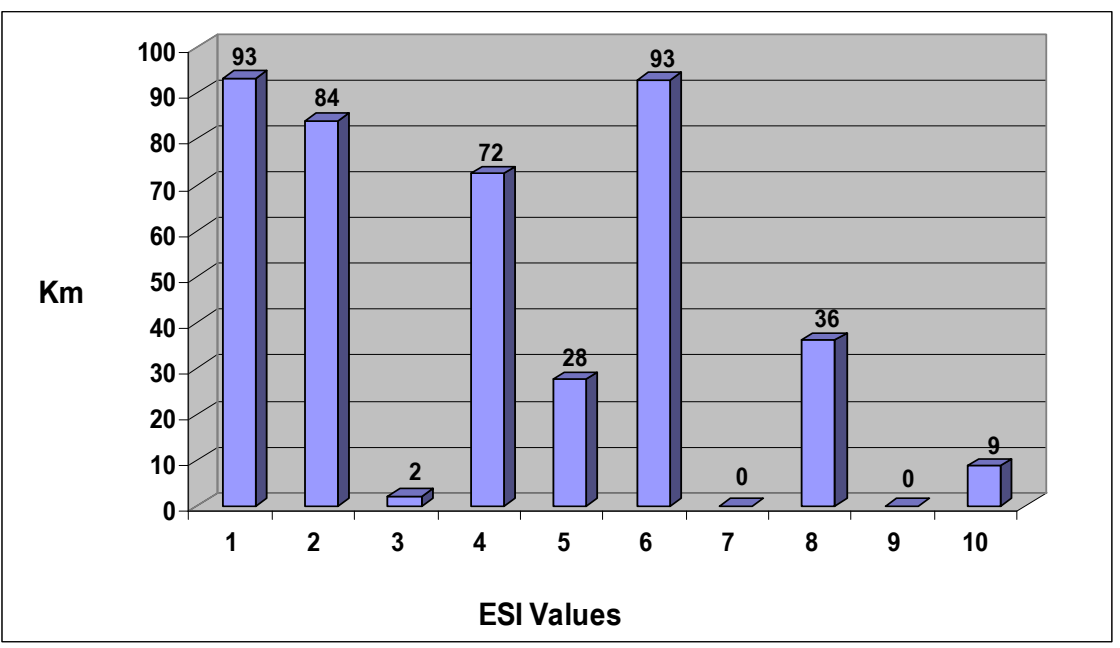

Figure 4: Coastal length of each ESI values in the Eastern Sicily shoreline.

\section{Conclusions}

The paper offers the opportunity to validate the tested methods and obtain an overview of the sensitivity to hydrocarbon spills in a particularly complex area where coexist important historical and archaeological resources, protected marine species and intense human activity, especially related to the tourism.

In addition, the results obtained in the pilot project confirmed that the used methodology provides a clear system for localising environmental, landscape and cultural priorities for the protection of those areas that will results most vulnerable.

The GIS database containing the collected data and their subsequently elaboration is a valuable instrument for the application of the principles of Integrated Coastal Zone Management by local communities and public administrations, as well as for the prevention of major environmental disasters from unforeseen hydrocarbons spill.

Ultimately, this project contains a series of technical information valuable for the development and the implementation of a specific Contingency Plan for the Ionian Sea, identifying high priority areas for the planning of preparedness and response actions aimed to reduce the risks and the impacts of marine pollution related to maritime hydrocarbon traffic.

\section{References}

[1] Cinquepalmi F., Traffico petrolifero nel Mediterraneo: il quadro normativo e le politiche ambientali. in "Biodiversità marina e strategie di riduzione del rischio connesso al trasporto di Idrocarburi", study day minutes, Rome, October 2005 
[2] Biliardo U., Mureddu G., Traffico petrolifero e sostenibilità ambientale. Unione petrolifera, 2005

[3] Cuttelod A. et al., The Mediterranean: a biodiversity hotspot under threat. Published by IUCN, Switzerland, 2008

[4] Slim H., Scovazzi T., Study of the current status of ratification, implementation and compliance with maritime agreements and conventions applicable to the Mediterranean Sea Basin-Part 1. AGRECO Consortium, 2009

[5] Ministero delle Infrastrutture e dei Trasporti, Relazione sull'attività delle autorità portuali. 2009

[6] ITOPF, Fate of Marine Oil Spills. ITOPF Technical Information Paper $\mathrm{N}^{\mathrm{o}} 2$, 2002

[7] IMO/IPIECA Report Series - Volume One: Sensitivity Mapping for Oil Spill Response. 1990-2005

[8] NOAA, Environmental sensitivity index guidelines. Version 3.0, 2002

[9] Wieczorek A., Dias-Brito D., Carvalho Milanelli J.C., Mapping oil spill environmental sensitivity in Cardoso Island State Park and surroundings areas, Sao Paulo, Brazil. Ocean \& Coastal Management, Volume 50, 2007 